\title{
EVALUATING THE COST-EFFECTIVENESS OF DIFFERENT GROUPS OF HYPERTENSION THERAPY: A PHARMACOECONOMIC STUDY
}

\author{
ROOBENA PARVEEN A ${ }^{1}$, VARA PRASANNA RAO M⿻丷 \\ Department of Pharmacy Practice, School of Pharmaceutical Sciences, Vels University, Pallavaram, Chennai - 600 043, Tamil Nadu, India. \\ Email: mvprasanna90@gmail.com \\ Received: 10 October 2018, Revised and Accepted: 11 December 2018
}

ABSTRACT

Objective: The study objective is to evaluate among the different groups of antihypertensive for their cost-effectiveness and to provide information about the effective management of hypertensives both clinically and economically.

Methods: This study involves 81 patients aged 18-80 years on antihypertensive treatment who were enrolled from December to May with daily dose calculation. It is performed to analyze cost-effectiveness in the management of clinical condition. Data collection form to be entered with age, sex, food habits, occupational status, clinical data, and drugs was used for treatment. Incremental cost-effectiveness ratio is calculated based on the incremental cost for "per mmHg" reduction and cost for "per patient" reaching target blood pressure (BP).

Result: Angiotensin receptor blockers (ARBs) show a significant average reduction of systolic BP (SBP) and beta-blockers (BBs) show an average reduction of diastolic BP (DBP). Angiotensin-converting enzyme inhibitors (ACEIs) are cost effective in SBP and calcium channel blockers are cost effective in maintaining DBP.

Conclusion: ARBs, BBs, and ACEIs show the effective management of hypertensives both clinically and economically.

Keywords: Antihypertensive, Cost-effectiveness, Systolic blood pressure, Diastolic blood pressure.

(C) 2018 The Authors. Published by Innovare Academic Sciences Pvt Ltd. This is an open access article under the CC BY license (http://creativecommons. org/licenses/by/4. 0/) DOI: http://dx.doi.org/10.22159/ajpcr.2018.v11s4.31738

\section{INTRODUCTION}

Hypertension (HTN) also known as high blood pressure (BP) is a condition where the BP has persistently raised in the blood vessels. Blood is carried to all parts of the body from the heart, and the heart pumps blood into the vessels. The force of blood pushing against the walls of the arteries is called as BP. If the pressure is high, it is harder to pump the blood from the heart [1]. HTN has a multifactorial etiology, which combines both environmental and genetic factors [2]. HTN is one of the risk factors for the development of all the major cardiovascular diseases such as coronary artery disease, peripheral artery disease, stroke, heart failure, and renal failure which commonly affect the elderly [3].

\section{Treatment strategies}

HTN management has two approaches, which are lifestyle modification and add-on drug therapy [4].

\section{Pharmacoeconomics}

In health care, an economic evaluation is defined as "a comparative analysis of alternative courses of action in terms of both their costs and consequences" [5]. It is a branch of health economics that deals with both the costs and benefits of the drug therapy applied to the healthcare system [6,7]. However, assessment of clinically obtained data is the part of economic evaluation and judgment. The role of new drug therapy is based mainly on the clinical evidence of drugs' harms and benefits [8].

Specific tools in the pharmacoeconomic analysis to allow the orderly and comprehensive collection of data [9]

1. Cost-consequence analysis

2. Cost-minimization analysis

3. Cost-effective analysis

4. Cost-utility analysis

5. Cost-benefit analysis

6. Cost of illness analysis
Need for pharmacoeconomic analysis in India

In a developing country like India, the total health expenditure is nearly $85 \%$ on drug which is a major financial burden on households. A major part of private health care spending in India goes to drug and per capita private drug estimates as USD 16. Due to limited resources and high cost of drugs, many people in India frequently face a choice buying medicines or food or other necessities. Hence, medicines and its costs do matter in India [10]. Pharmacoeconomics serves as a link between medicine and market economy [7]. Pharmacoeconomics implies the application of economic principles to evaluate pharmaceuticals [8]. The aim is to maximize health benefit for the community to be delivered considering the existing limited financial resources [7]

\section{METHODS}

A prospective cross-sectional study includes both genders of age between 18 and 80 years and excludes the patients who are pregnant and lactating women and patients with any comorbidity such as acute emergency hypertensive patients, renal transplant patients, and malignancy condition. The study group is categorized into two groups which include either monotherapy or combination therapy. Monotherapy includes angiotensin receptor blockers (ARBs), angiotensin-converting enzyme inhibitors (ACEIs), calcium channel blockers (CCBs), and beta blockers (BB). Combination therapy includes ARBs with CCBs or BBs or ACEIs. This study was approved by the Institutional Ethics Committee of VISTAS with reference number "VISTAS-SPS/IEC/I/2017/07." Patients on antihypertensive treatment were enrolled and studied with daily dose calculation. Study was performed to analyze cost-effectiveness in the management of clinical condition. Data collection form includes age, sex, occupational status, clinical data, and drugs used for treatment. Incremental cost-effectiveness ratio is calculated based on the incremental cost for "per mmHg" reduction and cost for "per patient" reaching target BP. The values were statistically evaluated by daily dose 
calculation and incremental cost for "per mmHg" reduction and cost for "per patient" reaching target BP.

Table 1: Data on patients enrolled for the study

\begin{tabular}{ll}
\hline Patient enrolment data & \\
\hline Number of male patients (\%) & $41(50.6)$ \\
Number of female patients (\%) & $40(49.3)$ \\
Total number of patients enrolled (\%) & $81(100)$ \\
\hline
\end{tabular}

Table 2: Social and clinical parameters

\begin{tabular}{lllll}
\hline Age (in years) & $\mathbf{1 8 - 3 0}$ & $\mathbf{3 1 - 5 0}$ & $\mathbf{5 1 - 7 0}$ & $\mathbf{7 1 - 8 0}$ \\
\hline $\begin{array}{l}\text { Duration of treatment } \\
\text { (in years) }\end{array}$ & 0 & $1-5$ & $6-10$ & $11-15$ \\
BMI & 0 & 25.82 & 26.19 & 25.34 \\
Weight gain (\%) & 0 & 11.11 & 28.39 & 2.46 \\
Weight loss (\%) & 0 & 22.21 & 32.01 & 3.70 \\
Family history (\%) & 0 & 17.28 & 35.80 & 1.23 \\
Smoking (\%) & 0 & 11.11 & 17.28 & 2.46 \\
Alcoholism (\%) & 0 & 4.93 & 9.87 & 0 \\
Stress (\%) & 0 & 16.04 & 25.92 & 3.70 \\
Obese (\%) & 0 & 11.11 & 18.51 & 1.23 \\
Active (\%) & 0 & 14.81 & 11.11 & 0 \\
Non-worker (\%) & 0 & 18.52 & 24.69 & 1.23 \\
Pensioner (\%) & 0 & 0 & 24.6 & 4.93 \\
\hline
\end{tabular}

BMI: Body mass index

Table 3: Therapy provided to selected patients $(n=81)$

\begin{tabular}{ll}
\hline Therapy & $\begin{array}{l}\text { Percentage of patients received } \\
\text { treatment }(\%)\end{array}$ \\
\hline Single-drug therapy & 79.01 \\
Two-drug combination therapy & 17.28 \\
Three-drug combination therapy & 3.71 \\
\hline
\end{tabular}

\section{RESULT}

Of 81 patients, 41 (50.6\%) were male and 40 (49.3\%) were female. Patients receiving single-drug therapy were $79.01 \%$, combination therapies were $17.28 \%$, and triple therapy were $3.71 \%$.

\section{SUMMARY AND CONCLUSION}

The aim of the present study was to perform cost-effectiveness analysis of antihypertensive drugs in a cardiology outpatient department. A total number of 81 patients were enrolled in this study (Table 1). Demographic study and cost-effectiveness analysis were performed for the patients, and the study has estimated the following results:

- Both genders are found to be affected by HTN, with an average age in the range of 51-70 years of age and 6-10 years of duration.

- Population within the range of 6-10 years of duration was found to have increased percentage of obese, smokers, alcoholism, stress, and family history.

- Population within the age group of 51-70 years was found to be non-workers with the increased weight loss (Table 2).

- An increased number of patients were treated effectively with single drug therapy (Table 3).

- $\quad$ ARBs were prescribed mostly for single- drug therapy. ARBs result in highest average reduction of systolic BP (SBP).

- A combination of ARBs with BBs was prescribed mostly for two-drug combination therapy and CCBs with ARBs has higher SBP average reduction.

- A combination of ARBs with BBs and CCBs was mostly prescribed for three-drug combination therapy and ARBs with ACEIs and BBs has higher average reduction of SBP.

- $\quad$ BBs result in higher average reduction of diastolic BP (DBP) in single drug therapy.

- ARBs with CCBs show a higher reduction of DBP in two-drug combination therapy (Table 4).

- $\quad$ ARBs with ACEIs and BBs have a higher average reduction of DBP (Table 4).

Table 4: Cost-effectiveness of anti-hypertensive drugs based on DBP

\begin{tabular}{lllll}
\hline Therapy & $\begin{array}{l}\text { Annual } \\
\text { cost (Rs.) }\end{array}$ & $\begin{array}{l}\text { Average } \\
\text { reduction (mmHg) }\end{array}$ & $\begin{array}{l}\text { Percentage of patients with target } \\
\text { DBP }\end{array}$ & $\begin{array}{l}\text { Cost/average } \\
\text { reduction (Rs.) }\end{array}$ \\
\hline ARB & 7774.5 & 4.3 & 100 & $\begin{array}{l}\text { Cost/target } \\
\text { DBP (Rs.) }\end{array}$ \\
BB & 3978.5 & 4.74 & 100 & 77.74 \\
ACE & 967.25 & 1 & 70 & 39.78 \\
CCB & 854.1 & 1.22 & 67 & 13.78 \\
ACE+CCB & 8336.6 & 1.7 & 100 & 967.25 \\
ARB+BB & 5551.65 & 2.82 & 80 & 700.08 \\
ARB+ACE & 3412.75 & 3.4 & 100 & 4903.88 \\
ARB+CCB & 3869.00 & 5.09 & 100 & 1968.67 \\
BB+ACE & 5354.55 & 2.6 & 100 & 1003.75 \\
ARB+CCB+BB & 9303.85 & 0.3 & 100 & 76.36 \\
ARB+BB+ACE & $11,245.65$ & 1.4 & 100 & 34.12 \\
\hline
\end{tabular}

DBP: Diastolic blood pressure, ARB: Angiotensin receptor blocker, CCB: Calcium channel blocker, ACE: Angiotensin-converting enzyme, BB: Beta-blocker

Table 5: Cost-effectiveness of antihypertensive drugs based on SBP

\begin{tabular}{|c|c|c|c|c|c|}
\hline Therapy & $\begin{array}{l}\text { Annual } \\
\text { cost (Rs.) }\end{array}$ & $\begin{array}{l}\text { Average } \\
\text { reduction }(\mathrm{mmHg})\end{array}$ & $\begin{array}{l}\text { Percentage of patients with target } \\
\text { SBP }\end{array}$ & $\begin{array}{l}\text { Cost/average } \\
\text { reduction (Rs.) }\end{array}$ & $\begin{array}{l}\text { Cost/target } \\
\text { SBP (Rs.) }\end{array}$ \\
\hline ARB & 7774.5 & 10.4 & 84 & 747.54 & 92.55 \\
\hline $\mathrm{BB}$ & 3978.5 & 9.4 & 90 & 423.24 & 44.20 \\
\hline ACE & 967.25 & 9.5 & 85 & 101.81 & 11.37 \\
\hline CCB & 854.1 & 7 & 80 & 122.01 & 10.67 \\
\hline $\mathrm{ACE}+\mathrm{CCB}$ & 8336.6 & 7 & 67 & 1190.94 & 124.42 \\
\hline $\mathrm{ARB}+\mathrm{BB}$ & 5551.65 & 10.5 & 100 & 528.72 & 55.51 \\
\hline $\mathrm{ARB}+\mathrm{CCB}$ & 3869.00 & 9.2 & 100 & 420.54 & 38.69 \\
\hline $\mathrm{BB}+\mathrm{ACE}$ & 5354.55 & 8.5 & 100 & 629.94 & 53.54 \\
\hline $\mathrm{ARB}+\mathrm{CCB}+\mathrm{BB}$ & 9303.85 & 7.8 & 100 & 1192.80 & 93.03 \\
\hline$A R B+B B+A C E$ & $11,245.65$ & 8.1 & 100 & 1388.35 & 112.45 \\
\hline
\end{tabular}

SBP: Systolic blood pressure, ARB: Angiotensin receptor blocker, CCB: Calcium channel blocker, ACE: Angiotensin-converting enzyme, BB: Beta-blocker 
- $\quad$ CCBs hold the lowest cost among the single-drug therapy (Table 4).

- ARBs with ACEIs hold the lowest cost among two-drug combination therapy (Table 5).

- ARBs with BBs and CCBs hold the lowest cost among three-drug combination therapy.

- Cost-effectiveness of anti-HTN drugs based on the cost/average reduction and cost/patients with target $\mathrm{BP}$.

- ARBs with CCBs show a significant reduction in BP. ACEIs show cost effective in the reduction per $\mathrm{mmHg}$ reduction of SBP. CCBs show the cost effective in the reduction per $\mathrm{mmHg}$ reduction of DBP. CCBs shows the cost effective to maintain the target BP (Tables 4 and 5).

\section{ACKNOWLEDGMENT}

The research work was carried out in the Department of Cardiology, and the researcher are thankful to Dr. Neo church and all the staff for extending all the cooperation during research work. We also acknowledge the efforts of the participant and contribution made by them.

\section{AUTHORS' CONTRIBUTIONS}

Concept, data collection, statistical analysis, and writing of article - Roobena Parveen A. Drafting with valuable corrections and guidance - Dr. Vara Prasanna Rao M.

\section{CONFLICTS OF INTEREST}

The authors have no conflicts of interest.

\section{REFERENCES}

1. WHO. A Global Brief on Hypertension Silent killer, Global Public Health Crisis. Geneva, Switzerland: WHO; 2013.

2. Sharma SK, Sawhney V. Awareness, stress, anxiety, and depression among hypertensive patients attending cardiac outpatient department in a super specialty hospital. Asian J Pharm Clin Res 2016;9:62-4.

3. Reaven GM. Insulin resistance, hyperinsulinemia, and hypertriglyceridemia in the etiology and clinical course of hypertension. Am J Med 1991;90:7S-12S.

4. Chobanian AV, Bakris GL, Black HR, Cushman WC, Green LA, Izzo JL Jr., et al. The seventh report of the joint national committee on prevention, detection, evaluation, and treatment of high blood pressure: The JNC 7 report. JAMA 2003;289:2560-72

5. Drummond M, Jönsson B, Rutten F. The role of economic evaluation in the pricing and reimbursement of medicines. Health Policy 1997;40:199-215.

6. Frick KD. Understanding cost-outcome analysis for interventions dealing with unpleasant symptoms. Adv Stud Nurs 2005;3:158-63.

7. Tsokeva ZH, Sokolova K, Radev S. Pharmacoeconomics in evaluating health care decisions. Trakia J Sci 2006;4:9-13.

8. Robertson J, Lang D, Hill S. Use of pharmacoeconomics in prescribing research. Part 1: Costs - moving beyond the acquisition price for drugs. J Clin Pharm Ther 2003;28:73-9.

9. Bevan D. Pharmacoeconomics: Cost effective choices. Int Anesth Res Soci Can J Anaesth 1993;40:693-5

10. Dolan P. Modeling valuations for EuroQol health states. Med Care 1997;35:1095-108 